\title{
Primary shunt hyperbilirubinaemia: a variant of the congenital dyserythropoietic anaemias
}

\author{
Arthur R. Bird, Elayne Knottenbelt, Peter Jacobs and J. Maigrot ${ }^{1}$ \\ University of Cape Town Leukaemia Centre and Department of Haematology, Groote Schuur Hospital, \\ Observatory, Cape, South Africa; and ${ }^{1}$ Rue Lees, Curepipe, Mauritius
}

\begin{abstract}
Summary: A 19 year old Mauritian male presented with episodic nausea, abdominal discomfort and jaundice. Unconjugated hyperbilirubinaemia and erythroid hyperplasia without dyserythropoiesis led to the diagnosis of primary shunt hyperbilirubinaemia. The similarity between congenital dyserythropoietic anaemia and this entity suggests that patients with these lesions can be considered within a single spectrum of disorders, characterized as congenital ineffective erythropoiesis.
\end{abstract}

\section{Introduction}

Primary shunt hyperbilirubinaemia (PSH) is a rare cause of jaundice, characterized by an elevated unconjugated serum bilirubin level, increased urobilinogen excretion, hyperplastic ineffective erythropoiesis with a normal red cell survival, and occasionally anaemia. ${ }^{1}$

Many of these features apply equally well to congenital dyserythropoietic anaemia (CDA), a syndrome in which prominent findings are ineffective erythropoiesis and dysplastic normoblasts in the bone marrow. Various subtypes have been described, based on morphological differences in these cells and antigenic alterations in the red cell membrane. ${ }^{2}$ Type I CDA is recognized by internuclear chromatin bridging and a disorganized chromatin pattern in the red cell precursors. Type II typically has numerous binucleate normoblasts, submembranous cisternae in the red cells and their precursors, best seen on electron microscopy, a positive Ham's test with a proportion of donor sera and a markedly increased expression of $i$ antigen on the red cells. Type III presents as a moderate macrocytic anaemia, with giant multinucleate normoblasts in the bone marrow. Type IV and other atypical variants have also been recognized. ${ }^{3-7}$

We report a patient who presented with mild

Correspondence: Professor P. Jacobs, M.D., Ph.D., Department of Haematology, University of Cape Town Medical School, Anzio Road, Observatory 7925, Cape, South Africa.

Accepted: 13 November 1990

Supported by the University of Cape Town Leukaemia Centre and Staff Research (Foote and Cancer) Fund, the Gwendoline Moore Trust, The Medical Research Council, the National Cancer Association, and the Michael Chanani, Kaliski and M.A. Richardson Bequests. jaundice and was found to have an unconjugated hyperbilirubinaemia and ineffective erythropoiesis. Anaemia was not initially present and dyserythropoiesis was mild, with none of the morphological features associated with CDA. His brother has similar clinical and haematological features, and a cousin has pyruvate kinase deficiency. In addition, two of his uncles have an ill-defined syndrome, associated with periodic attacks of mild jaundice, but blood samples were not available for study. No other family members were apparently abnormal.

\section{Case report}

The propositus is a 19 year old male from Mauritius who presented with a 4-year history of episodic nausea and abdominal discomfort. On examination the only abnormal physical finding was the presence of mild jaundice. The spleen was impalpable and of normal size on ultrasonography.

Initial haematology showed the haemoglobin to be $14.7 \mathrm{~g} / \mathrm{dl}$, red cell count $4.36 \times 10^{12} / 1$, haematocrit 0.44 l/1, MCV $99.4 \mathrm{fl}$, MCH $33.6 \mathrm{pg}, \mathrm{MCHC}$ $33 \mathrm{~g} / \mathrm{dl}$, white cell count $4.2 \times 10^{9} / 1$ and platelets $258 \times 10^{9} / 1$. The reticulocyte index was $0.2 \%$. The differential white cell count was normal and the red cells showed mild macrocytosis and occasional basophilic stippling. Subsequent blood counts have shown an essentially similar picture, with the haemoglobin dropping to $13.4 \mathrm{~g} / \mathrm{dl}$ on one occasion.

The erythrocyte sedimentation rate was $5 \mathrm{~mm}$ in the first hour. Total and conjugated serum bilirubin was 60 and $6 \mu \mathrm{mol} / 1$, respectively. Liver enzymes and serum lactic dehydrogenase were normal. Urine urobilinogen was positive on labstix screening and faecal urobilinogen was $1200 \mathrm{mg} / 100 \mathrm{~g}$ stool (normal range $<200 \mathrm{mg} / 100 \mathrm{~g}$ wet weight). 
The serum haptoglobin was decreased. The serum and red cell folate and vitamin B12 levels were normal. Serum iron was $140 \mu \mathrm{g} / \mathrm{dl}$ (normal range 46-173), total iron binding capacity $290 \mu \mathrm{g} / \mathrm{dl}$ (normal range 264-376), with a saturation of transferrin at $48 \%$ (normal range $18-52$ ). Serum ferritin was $290 \mu \mathrm{g} / 1$ (normal range 20-220). 2,3 DPG, glucose-6-phosphate dehydrogenase (G6PD), pyruvate kinase and $5^{\prime}$ pyrimidine nucleotidase assays were all normal, as were the Ham's test and a full screen for abnormal haemoglobins. Bone marrow aspiration and trephine biopsy showed erythroid hyperplasia, with mild to moderate megaloblastic maturation; while occasional binucleate normoblasts were present, dyserythropoiesis was not a feature. Reticuloendothelial and normoblast iron was increased, but ring sideroblasts were absent. Ultrastructural studies of the marrow confirmed those findings seen on light microscopy. Red cell phenotyping showed no abnormalities of the I and $i$ antigen.

Radionuclide studies, using standard methods, ${ }^{8}$ showed $\mathrm{T}_{50}{ }^{51} \mathrm{Cr}$ to be 24 days (normal range $30 \pm 4$ ), with a calculated mean red cell lifespan of 92 days (normal range $120 \pm 10$ ). $\mathrm{T} \frac{1}{2}$ for ${ }^{59} \mathrm{Fe}$ plasma clearance was $36 \mathrm{~min}$ (normal range 70-140), plasma iron turnover was $1.75 \mathrm{~g} \mathrm{Fe} /$ $100 \mathrm{ml}$ blood/day (normal range $0.45-0.9$ ) and red cell utilization was $45 \%$ at 14 days (normal $>80 \%$ ).

The family pedigree is shown in Figure 1. Three of the patient's 4 siblings were tested. One brother (III-2) was normal, while the other had an unconjugated hyperbilirubinaemia and haematological features practically identical to that of the propositus. An older sister (III-4) was haematologically entirely normal, as were both parents. One of the patient's uncles was haematologically normal (II-5), while another had an obvious macrocytosis (II-4). Only one aunt was tested (II-6) and she was haematologically normal. Pyruvate kinase deficiency was documented in the propositus' cousin (III-1), but assays for pyruvate kinase in several first-degree relatives revealed normal values.

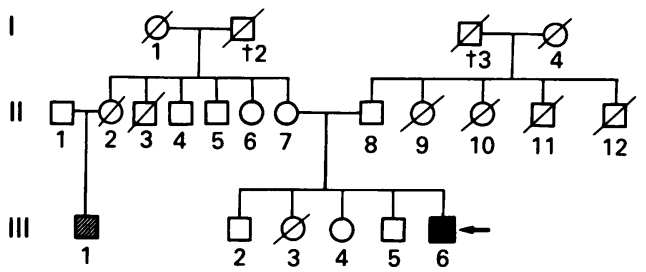

Figure 1 The family pedigree. The propositus is indicated with an arrow, and a cousin (III -1 ) had pyruvate kinase deficiency and is indicated by cross-hatching. Lines through other family members indicate that they have not been available for testing.

\section{Discussion}

Shunt hyperbilirubinaemia describes the increase in bilirubin production associated with ineffective erythropoiesis, which is usually secondary to deficiencies of folate or vitamin B12, occurring also in thalassaemia and CDA. A rare primary variant has been described in a group of related young adults ${ }^{9}$ who were all mildly to moderately jaundiced, modestly anaemic with mild reticulocytosis, and all had palpable splenomegaly. Apart from occasional spherocytes the red cells were morphologically normal. The hyperplastic marrows were normoblastic and marked iron deposition in the Kupffer cells of the liver was noted in 2 patients. Radionuclide studies showed normal red cell survival but ineffective erythropoiesis. There have been 2 other reports of similar cases, in one of which there was also a family history of jaundice. ${ }^{10,11}$

Our patient is unusual in that the haemoglobin level was generally normal, whereas a moderate anaemia has characterized most other reported cases. The pattern of inheritance is obscure, since full family studies are not available, but jaundice in only the males suggests sex-linked transmission. Management has been reassurance of the patient and folate supplementation. However, the expanded body iron stores occurring without transfusion or iron medication are cause for concern, since hepatic disease in similar conditions has been reported. ${ }^{12}$ The pathogenesis is not clear, but has been attributed to increased plasma iron turnover. ${ }^{13}$ The diagnosis of Gilbert's syndrome seems unlikely since there is a marked elevation of faecal urobilinogen levels. In Gilbert's syndrome this is either normal or reduced. ${ }^{14}$ Although haematological abnormalities have been reported in Gilbert's syndrome, these have been demonstrated only by radionuclide studies, and anaemia and macrocytosis have not been a feature. ${ }^{15}$

The pathogenesis of both PSH and CDA centres on markedly ineffective erythropoiesis. The precise defect at the cellular level remains obscure, although structural and transport defects of the membrane have been described. ${ }^{16,17}$ In view of the clinical, haematological and biochemical similarities, it would seem appropriate to regard both PSH and CDA syndromes as part of a single spectrum characterized by congenitally ineffective erythropoiesis.

\section{Acknowledgements}

We thank Keren Hounsell for bibliographic assistance, Professor Ralph Kirsch for reviewing the paper, and Jackie Davies for help with preparation of the manuscript and its typing. 


\section{References}

1. Israels, L.G. The bilirubin shunt and shunt hyperbilirubinemia. In: Popper, H. \& Schaffner, F (eds). Progress in Liver Disease. III. Grune and Stratton, Inc., New York, 1970, pp. $1-12$.

2. Lewis, S.M. \& Verwilghen, R.L. Dyserythropoiesis and dyserythropoietic anemias. In: Brown, E.B. (ed.) Progress in Hematology 1973, pp. 99-129.

3. Benjamin, J.T., Rosse, W.F., Daldorf, F.G. \& McMillan, C.W. Congenital dyserythropoietic anemia-type IV. $J$ Pediatr 1975, 87: 210-216.

4. Samson, D., Halliday, D. \& Chanarin, I. Congenital dyserythropoietic anaemia: response to splenectomy and quantitation of ineffective erythropoiesis. J Clin Pathol 1977, 30: 184-190.

5. Sansone, G. A new type of congenital dyserythropoietic anaemia. Br J Haematol 1978, 39: 537-543.

6. Lowenthal, R.M., Marsden, K.A., Dewar, C.L. \& Thompson, G.R. Congenital dyserythropoietic anaemia (CDA) with severe gout, rare Kell phenotype and erythrocyte, granulocyte and platelet membrane reduplication: a new variant of CDA type II. Br J Haematol 1980, 44: 211-220.

7. Bird, A.R., Karabus, C.D. \& Hartley, P.S. Type IV congenital dyserythropoietic anemia with an unusual response to splenectomy. Am J Pediatr Hematol Oncol 1985, 7: 196-199.

8. Dacie, J.V. \& Lewis, S.M. (eds) Laboratory methods used in the investigation of the haemolytic anaemias. In: Practical Hematology, 6th edition. Churchill Livingstone, Edinburgh, 1984, pp. 138-151.

9. Israels, L.G., Suderman, H.J. \& Ritzmann, S.E. Hyperbilirubinemia due to an alternate path of bilirubin production. Am J Med 1959, 27: 693-702.
10. Greendyke, R.M. Congenital refractory normoblastic anemia with jaundice and ineffective erythropoiesis. Am J Med 1962, 32: 611-617.

11. Frank, D.J., DuSol, M. \& Schiff, E.R. Primary shunt hyperbilirubinemia with secondary iron overload: a case report. Gastroenterology 1979, 77: 754-757.

12. Cazzola, M., Barosi, G., Bergamaschi, G. et al. Iron loading in congenital dyserythropoietic anaemias and congenital sideroblastic anaemias. Br J Haematol 1983, 54: 649-654.

13. Cavill, I., Worwood, M. \& Jacobs, A. Internal regulation of iron absorption. Nature 1975, 256: 328-329.

14. Fleischner, G.M. \& Kirsch, R.E. Familial hyperbilirubinemic syndromes: In: Dietschy, J.M. (ed.) Disorders of the Gastrointestinal Tract. Disorders of the Liver. Nutritional Disorders. Grune and Stratton, New York, 1976, pp. 324-328.

15. Metreau, J.M., Yvart, J., Dhumeaux, D. \& Berthelot, P. Role of bilirubin overproduction in revealing Gilbert's syndrome: is dyserythropoiesis an important factor? Gut 1978, 19: 838-843.

16. Anselstetter, V., Horstmann, H.J. \& Heimpel, H. Congenital dyserythropoietic anaemia, types I and II: aberrant pattern of erythrocyte membrane proteins in CDA II, as revealed by two-dimensional polyacrylamide gel electrophoresis. $\mathrm{Br} J$ Haematol 1977, 35: 209-215.

17. Howe, R.B., Branda, R.F., Douglas, S.D. \& Brunning, R.D. Hereditary dyserythropoiesis with abnormal membrane folate transport. Blood 1979, 54: 1080-1090. 